\title{
Coronovirus Hastalığı 2019 Tanısı ile Hastanede Yatan Çocuklarda Klinik, Laboratuar, Radyolojik Bulguların ve Sonuçların Değerlendirilmesi
}

\section{Evaluation of Clinical Characteristics, Laboratory, Radiological Findings and Outcomes of Hospitalized Children with Coronavirus Disease 2019}

\author{
${ }^{1}$ Fatih VAROL, ${ }^{2}$ Oznur ESER,${ }^{2}$ Gunay KAPLAN, ${ }^{2}$ Aysun BOĞA, ${ }^{3}$ Betul Zehra PIRDAL, ${ }^{2}$ Sirin GUVEN \\ ${ }^{1}$ University of Health Science, Department of Pediatrics, Division of PICU, Prof. Ilhan Varank Sancaktepe Training and Research Hospital, \\ Istanbul, Turkey \\ ${ }^{2}$ University of Health Science, Department of Pediatrics, Prof. Ilhan Varank Sancaktepe Training and Research Hospital, Istanbul, Turkey \\ ${ }^{3}$ Department of Public Health, Cerrahpasa Faculty of Medicine, Istanbul University- Cerrahpasa, Istanbul, Turkey
}

\begin{abstract}
Fatih Varol: https://orcid.org/0000-0002-2424-6887
Oznur Eser: https://orcid.org/0000-0002-2372-5026

Gunay Kaplan: https://orcid.org/0000-0001-7752-445X

Aysun Boga: https://orcid.org/0000-0002-9574-9529

Betul Zehra Pirdal: https://orcid.org/0000-0003-0127-9296

Sirin Guven: https://orcid.org/0000-0001-8727-5805
\end{abstract}

\section{ÖZ}

Amaç: Çalışmamızda COVID-19 tanısı ile hastanede yatan çocukların epidemiyolojik, klinik özellikleri, laboratuvar/radyolojik bulguları ve sonuçları hakkındaki bilgilerimizi değerlendirdik.

Materyal ve Metot: $\mathrm{Bu}$ retrospektif tek merkezli çalıșma, 16 Mart 2020 - 26 Nisan 2020 tarihleri arasında İstanbul Sancaktepe Eğitim ve Araştırma Hastanesi Pediatri Kliniğinde yatan 54 COVID-19 tanılı çocuk hasta üzerinde gerçekleştirildi.

Bulgular: Hastalarımızın ortanca yaş1 121,5 ay (1-214 ay) idi. Hastaneye yatırılan 54 çocuk hastanın \% 48,'i $(n=26)$ kadın, \%51,9'u ( $\mathrm{n}=28)$ erkekti. En sık görülen semptom öksürüktü ( $\mathrm{n}=24, \% 44,4)$. Ortalama yatış süresi 5 gündü (1-13 gün arasında). PCR test sonuçlarına göre 24 (\% $44,4)$ hasta pozitif, $30(\% 55,6)$ hasta negatifti. 54 çocukta beyaz küre sayısı (WBC), mutlak nötrofil sayısı (ANC) anlamlı olarak düsüktü ve CRP düzeyleri PCR negatif hastalarda anlamlı olarak daha yüksekti. Bilgisayarlı tomografi 26 hastamıza çekildi ve $19(\% 73,1)$ BT klasik olas1 / belirsiz COVID-19 baskın paterni ile uyumlu idi. PCR negative hastalarımızda oksijen gereksinimi anlaml derecede yüksekti.

Sonuç: PCR test sonuçlarının düşük hassasiyetinin bir sonucu olarak, klinisyenler COVID-19'un tanı ve tedavisine karar verirken klinik belirti ve semptomları ön planda düşünmelidir.

Anahtar Kelimeler: Çocuk, klinik özellikleri, Covid19

\section{ABSTRACT}

Objective: We assessed our knowledge about the epidemiological, clinical characteristics, laboratory/radiological findings, and outcomes of hospitalized children with COVID-19.

Materials and Methods: This retrospective single-center study was conducted on 54 children with COVID-19 who were hospitalized from March 16, 2020, to April 26, 2020, in the Pediatric Department at Sancaktepe Training \&Research Hospital Istanbul, Turkey.

Results: The median age of our patients was 121.5 months (range 1-214 months), of the 54 hospitalized children, $48.1 \%(\mathrm{n}=26)$ were female, and $51.9 \%(\mathrm{n}=28)$ were male. The most common symptom was cough $(n=24,44.4 \%)$. The median duration of hospitalization was five days (range 1-13 days). According to the PCR test results, 24 (44.4\%) patients were positive, and $30(55.6 \%)$ were negative. Among 54 children, white-cell count (WBC), absolute neutrophil count (ANC) were significantly lower, and CRP levels were significantly higher in PCR negative patients. Computed tomography was performed in 26 children, and $19(73.1 \%)$ CT scans were consistent with classic/probable/indeterminate COVID-19 predominant patterns. Oxygen requirement was significantly higher in our PCR negative patients.

Conclusion: As a result of the low sensitivity of PCR test results, clinicians should consider clinical signs and symptoms in deciding on the diagnosis and treatment of COVID-19.

Keywords: Children, clinical features, Covid19

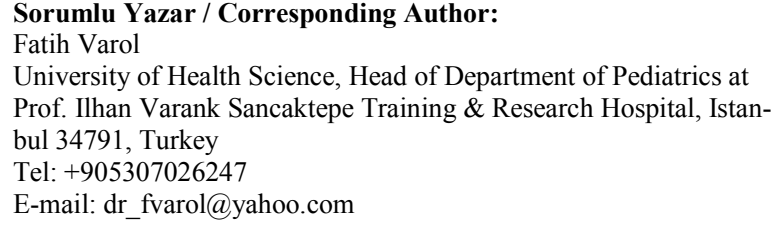

Atıf / Cited: Varol F, et al. Evaluation of Clinical Characteristics, Laboratory, Radiological Findings and Outcomes of Hospitalized Children with Coronavirus Disease 2019. Online Türk Sağlık Bilimleri Dergisi 2021;6(1):1-11. doi: 10.26453/otjhs.775502 


\section{INTRODUCTION}

Coronavirus disease 2019 (COVID-19),caused by the novel severe acute respiratory syndrome coronavirus 2 (SARS-CoV-2), started as a local public health problem in China and spread rapidly to many countries and was declared as a pandemic by the World Health Organization (WHO) on March 11. ${ }^{1}$ There has been a fast increase both in adult and pediatric cases since the first case was reported in Turkey on March 11. Many studies until now described that children develop less severe symptoms or critical illness compared to the adults, and most of the infected children are asymptomatic or present with atypical symptoms, such as lowgrade fever, vomiting, diarrhea, mild fatigue, cough without any signs of pneumonia or shortness of breath; thus, they can visit many outpatient healthcare centers before becoming a confirmed case and spreading the virus. ${ }^{2-8}$ Until now, a few severe/critical pediatric hospital-lized series was published. ${ }^{6,7}$ The data about the clinical course of the disease in children is limited, while treatment guidelines and outcomes in hospitalized children are not well known. The scientific board created by the Turkish Ministry of Health has developed a new treatment and follow-up an algorithm for clinicians in a very short time. The purpose of this study was to report our experience regarding demographic, clinical, laboratory, radiological findings, and outcomes of hospitalized children with COVID-19.

\section{MATERIALS AND METHODS}

Retrospective assessment was performed 54 hospitalized children with COVID-19 in the Pediatric Department at Sancaktepe Training \&Research Hospital Istanbul, Turkey, from March 16, 2020 to April 26, 2020. Informed consent was obtained from all parents before hospitalization. Approvels were received by the Ministry of Health and the ethics committee of the instution (Date: 28/04/2020, decision no: 139).

Study Design: Children were tested, treated, and followed-up by the same Pediatric COVID-19 team educated to take appropriate samples, and they were isolated in a single-person room. Personal protective equipment (PPE) was used to limit the risk for healthcare providers (HCPs) infection. Infants less than two months of age with pnomoniawere hospitiliazied for treatment.

For older than two months of age hospitalization criteria identified as follows; hypoxemia $\left(\mathrm{SpO}_{2}\right.$ $\leq 92 \%$ ), signs of respiratory failure such as nasal flares and grunting breathing, tachypnea, no feeding with dehydration or vomiting, chronic conditions (e.g., congenital heart disease, chronic lung disease, chronic premature disease, infectious chronic respiratory conditions such as cystic fibrosis, bronchiectasis, immunodeficiency), no response to oral antibiotics. ${ }^{9}$ Hospitalized children were possible cases in terms of covid 19 infection, according to the Ministry of Health report. ${ }^{10}$

Children, who had exposure history, clinical symptoms associated with COVID-19, together with abnormal chest X-ray or computed tomography (CT) findings and positive real time reverse transcriptase polymerase chain reaction (RT-PCR) test, were determined as confirmed cases. Laboratory tests such as complete blood count, C-reactive protein (CRP) and blood biochemistry were performed. Blood cultures were used in differential diagnosis of secondary bacterial infections. Nasal and pharyngeal swab RT-PCR assay to reveal SARS-CoV-2 was used according to the World Health Organization's guidance. The demographics, clinical symptoms, severity of disease, comorbid disease, transfer to the pediatric intensive care unit (PICU), laboratory findings, radiographic images (chest X-ray and CT) on all patients admitted to the hospital were obtained from our electronic hospital records and patients form filled upon admission. Fever was defined as an axillary temperature of $\geq 37.2^{\circ} \mathrm{C}$. Lymphocytopenia and thrombocytopenia was defined as a count of less than 1500 cells $/ \mathrm{mm}^{3}, 150,000$ cells $/ \mathrm{mm}^{3}$, respectively. Hypoxemia was recorded as oxygen saturation $\left(\mathrm{SpO}_{2}\right) \leq 92 \%$ on room air. The severity of COVID-19 was classified as mild (upper respiratory tract infection symptoms such as sore throat, fever, cough, vomiting, diarrhea and normal radiographic images), moderate (pneumonia, fever, cough, without hypoxemia and shortness of breath, or asymptomatic chest X-ray/CT lung lesions), severe (respiratory distress, hypoxemia, severe dehydration and signs of rhabdomyolysis) and critical (respiratory failure requiring mechanical ventilation, organ failure, myocardial injury and shock). The severity of pneumonia was assessed according to the Turkish Thoracic Society (TTS) guideline as mild, moderate or severe pneumonia. ${ }^{9}$ As it has been known for a long time, CT imaging was not performed in all pediatric patients hospitalized because $\mathrm{CT}$ increases the risk of cancer through the radiation it gives, instead, it was performed in patients with 
severe pneumonia in the light of a current publication that compiled previous studies. ${ }^{11}$

Chest radiography was performed on the basis of history and physical examination. Standard symptomatic and respiratory supportive treatment was initiated. Children with critical disease were transferred to the PICU. Critically ill children are children who need respiratory support (such as CPAP, mechanical ventilation), need vasoactive drugs, decrease in Glasgow coma score, and originate multiple organ failure during hospitalization. ${ }^{9}$

Statistical Analysis: SPSS v.21 (SPSS Inc., Chicago, IL, USA) was used for statistical analysis. Shapiro-Wilk tests, histograms and probability plots were used for assessing normality. Results were presented asmean (SD) for normally distributed variables and, median (Minimum-maximum) for non -normally distributed variables. Categorical variables were presented with frequency and percentage. Comparisons of the groups for continuous variables were made by Independent Samples T-test or Mann-Whitney U test, where appropriate. Chisquare test and Fisher's Exact test was used to analyze categorical variables, where appropriate. All tests are two-sided and the significance level was accepted as $\mathrm{p}<0.05$.

\section{RESULTS}

A total of 54 children required hospitalization for SARS-CoV-2. The median age of our patients was 121.5 months (range 1-214 months). Among 54 patients, $48.1 \%(n=26)$ were female and $51.9 \%(n=28)$ were male. Gender distribution according to PCR and clinical evaluation was not statistically significant. Twenty-four (44.4\%) patients had positive and $30(55.6 \%)$ had negative PCR test results. Of our hospitalized patients, $18(33.3 \%)$ had no contact history but they had definite clinical/radiological signs and symptoms of COVID-19; 36 (66.7\%) had contact history with confirmed COVID-19 family members. The absence of contact history in PCR negative cases $(n=15,50 \%)$ was found to be statistically significantly higher than in PCR positive cases $(n=3,12.5 \%)(p=0.014)$. Demographic characteristics of the patients are shown in Table1.

The most common symptom of the patients was cough $(n=24,44.4 \%)$, followed by fever $(n=19,35.2$ $\%)$, shortness of breath $(\mathrm{n}=7,13 \%)$, vomiting and diarrhea $(n=3,5.6 \%)$ and smell/taste loss $(n=1$, $1.9 \%$ ) (Figure 1). There was no statistically significant difference between PCR positive and negative children in clinical presentation and mild/moderate disease severity. All severe and critical children were PCR negative.

The median duration of hospitalization was five days (range 1-13 days), and there was no significant difference between PCR positive and negative children.

When we evaluated the laboratory test results of our patients, white-cell count (WBC), absolute neutrophil count (ANC) were significantly lower in PCR positive group than in $\mathrm{PCR}$ negative group $(p<0.001)$. In the PCR negative group $(90 \%)$, the proportion of patients with an ANC value $>3000$ was significantly lower than the proportion of the PCR positive group $(54 \%)(p=0.003)$. Neutrophil lymphocyte ratio (NLR: cut-off $>3.13$ ) was also higher in PCR negative group $(\mathrm{p}<0.001)$. The number of children with higher CRP levels was statistically significantly higher in the PCR negative $(n=16$, $53.3 \%)$ than in the PCR positive $(n=6,25 \%)$ group (p:0.035). No statistically significant difference was observed in biochemical parameters between the groups (Table 2). Among 43 children, chest X-Ray findings were normal in $16(37.2 \%)$, abnormal in 27 $(62.8 \%)$ of children. Nearly two-thirds ( $n=19$, $73.1 \%$ ) of the 26 performed CT scans were consistent with classic/probable/indeterminate COVID-19 predominant patterns. In the PCR negative group, 9 $(60 \%)$ children had classic/probable/indeterminate COVID-19 CT scan images. The CT severity was determined as mild, moderate and severe in 10 (52.6\%), $6(31.6 \%)$ and $3(15.8 \%)$ children, respectively (Table 3). Comorbidities such as asthma, epilepsy, IBD and DM were reported in three patients (5.5\%). Only one critically ill patient $(1.9 \%)$ required transfer to the pediatric intensive care unit (PICU).

Oxygen saturation on admission was in normal range. The median $\mathrm{SpO}_{2}$ was significantly lower in the PCR negative group with a ratio of $95.5 \%$ (range 88-99) compared to the PCR positive group, which had a ratio of $98 \%$ (range $92-100)(p<0.0011)$. Oxygen requirement and duration of oxygen treatment day were significantly higher in our PCR negative patients than in PCR positive $(\mathrm{p}<0.001)$. Vital signs, such as fever, heart rate and oxygen requirement, duration of oxygen treatment and blood gas analysis were not statistically significantly different between mild and moderate patients (Table 4).

Symptomatic and supportive treatment administered to hospitalized children. Azithromycin, chloroquine, azithromycin plus chloroquine were administered in 13,2 , and 14 patients, respectively. ECG monitoring 
was performed in children treated with azithromycin and chloroquine by a pediatric cardiologist.

\section{DISCUSSION AND CONCLUSION}

A few studies assessed the clinical characteristics of hospitalized children in PICU. ${ }^{5-7}$ Although a large proportion of children are asymptomatic and less severely affected, symptomatic cases required hospitalization. We assessed the clinical characteristics, severity of disease and early outcomes of children with COVID-19 hospitalized in the general pediatric unit. A study from Canada reported that $2.2 \%$ of patients younger than 20 years of age were hospitalized, compared to $10.4 \%$ in those aged $20-59$ years and $35.6 \%$ in $\geq 60$ years old. Of 581 tested children in our study, $54(9.3 \%)$ were hospitalized. Children of all ages are susceptible to COVID-19 infection. ${ }^{2-7}$ The median age of our patients was similar to those previously reported. ${ }^{5,7,12}$ Contrary to slightly male predominance in adults, the gender difference in children was not significant, ${ }^{3,5-7}$ as we determined in our study.

Reported transmission in children is by close contact with infected adults or by exposure to epidemic areas; in fact, more than $75 \%$ of patients had a household contact history. ${ }^{2,5}$ Paquette et al. found that $20.4 \%$ of children were exposed internationally, $9.6 \%$ had contacts with travelers from affected areas, $58.7 \%$ had contact with infected cases in Canada and $11.3 \%$ had no contact history. ${ }^{5}$ Initially in our country, only children with travel history or children, who contacted an infected person, and presented at least one symptom were tested, but the algorithm was changed rapidly. The recommendation was to test children with symptoms and signs of COVID19. So, the number of daily pediatric cases also increased concomitantly. PCR results were positive in only $44.4 \%$ of our hospitalized cases; most of the cases were PCR negative, they were clinically or radiologically diagnosed. PCR test negativity was higher in patients without contact history. Considering the droplet transmission of disease, significantly higher number of PCR negative patients without a household exposure may suggest the possibility of another transmission route. Previous studies showed that the predictivity of viral RNA RT -PCR swab test dependson the site of sampling and on time from exposure to onset of symptoms (stage of disease). The test has high specificity but lowmoderate sensitivity (range $32 \%-63 \%$ ). ${ }^{13,14}$ In our study, PCR negative children were more likely to have severe and critical disease than PCR positive.
The PCR test negativity can be explained not only by low-moderate sensitivity of the test, but also it might be due to the migration of virus into the tissues. Negative tests need to be interpreted with caution. Patients with a negative PCR test and clinical symptoms consistent with COVID-19 should be considered as infected and should be isolated, and followed according to the COVID-19 guidelines recommendations. Therefore, a negative PCR test result does not rule out the disease, especially if we have a high clinical suspicion. Reported laboratory findings are lymphopenia and elevated inflammatory markers. ${ }^{2,3,8,15,16}$ We found that increased NLR and CRP levels was significantly higher in PCR negative children. Lymphopenia $<1500$ cells $/ \mathrm{mm}^{3}$ was revealed only in $12(22 \%)$ of hospitalized children. Considering the higher rates of negative test results $(70.9 \%)$ and diagnosis based only on clinical features among children, the authors suggested that these cases might be caused by a different respiratory infection other than COVID-19. ${ }^{2}$

Studies of radiologic findings in pediatric patients with COVID-19 were limited and were different from adults; the authors suggested that early chest CT screening "is a feasible clinical protocol in children". ${ }^{17,18}$ In our study, CT scan was performed selectively in 26 symptomatic children. Our result found that nearly $73 \%$ of children had classic/ probable/indeterminate COVID-19 predominant patterns according to CT scan findings. The CT scan images were severe only in $3(15.8 \%)$ out of 26 children with classic/probable/indeterminate COVID-19 predominant pattern. Severe CT findings were detected in $2(22.2 \%)$ of PCR negative children, which confirmed the importance of clinical symptoms for diagnosis. The most commonly reported symptom in children is fever, followed by dry cough and fatigue, some patients have sore throat, runny nose, headache, vomiting and diarrhea. ${ }^{2-4} \mathrm{Lu}$ et al evaluated 171 children with confirmed COVID-19, who were treated at the Wuhan Children's Hospital in China. They reported that the most common symptoms were cough $(48.5 \%)$, pharyngeal erythema $(46.2 \%)$, and fever $(41.5 \%){ }^{3}$ In accordance with the very recently published studies, we found that the most common symptoms at admission were cough and fever. ${ }^{5,6,19}$ Other common symptoms were shortness of breath, vomiting and diarrhea. Children with comorbidities such as congenital heart disease, severe malnutrition and those with immune deficiency or immunocompromised status are at risk for severe disease. ${ }^{20} \mathrm{~A}$ few critical and mortal cases in children 
were reported in the published studies before April $26,2020 .^{2-4,15,16}$ In correlation with this findings, four $(7.4 \%)$ of our cases were severe and one $(1.9 \%)$ was critical; there was no death in our study. The overall case fatality rate in North American PICUs was $4.2 \%$. The patients who died were 12 to 17 years old and $80 \%$ of critically ill children had underlying comorbidities. ${ }^{7}$ Contrary to our results, recently published studies reported a higher rate of severe disease requiring transfer to the PICU (range from $13.2 \%$ to $28 \%$ ). ${ }^{5,6}$ The percentage of PICU admissions was highest among children with reported underlying comorbidities. ${ }^{6,7}$

It is unclear which children need antiviral and immunomodulatory therapy, especially because of the high rate of asymptomatic infected children. We need more information and global guideline for the treatment of pediatric patients. In a study from China, COVID-19 children were treated with aerosolized interferon alpha, lopinavir-ritonavir syrup, and supplemental oxygen. ${ }^{21}$ Up to now, no anti-viral treatment officially approved for the prevention or management of the COVID-19. Only supportive treatment was administered to our patients. The limitations of our study were the small sample size of hospitalized children, and the second and third sample collection were not routinely obtained from all patients; thus, the duration of viral RNA clearance could not be determined, and testing for other respiratory viral pathogens was not performed from all patients.

Although children are less affected and have mild symptoms, pediatricians should be aware that the disease in children can also be severe and critical. Regardless of the PCR test results, clinical symptoms with CT scan images may help the diagnosis of COVID-19.

Ethics Committee Approval: Our study was approved by the Umraniye Training and Research Hospital Noninvasive Researchs Ethics Committee (Date: 28/04/2020, decision no: 139).

Conflict of Interest: No conflict of interest was declared by the authors.

Author Contributions: Concept - FV, SG; Supervision - FV, AB, SG; Materials - OE, GK; Data Collection and/or Processing - FV, AB; Analysis and/ or Interpretation - BZP, FV, SG; Writing-FV, SG.

Peer-review: Externally peer-reviewed.
1. WHO/2019-nCoV/Situation Report-99. Geneva, Switzerland: World Health Organization. https:// www.who.int/docs/default- source/ coronaviruse /situation-reports. Accessed date April 28, 2020.

2. Dong $\mathrm{Y}, \mathrm{Mo} \mathrm{X}, \mathrm{Hu} \mathrm{Y}$, et al. Epidemiology of COVID-19 among children in China. Pediatrics. 2020;145(6):e20200702. doi:10.1542/peds.20200702

3. Lu X, Zhang L, Du H, et al. SARS-CoV-2 infection in children. N Engl J Med. 2020;30 (17):1663-1665. doi:10.1056/NEJMc2005073

4. Castagnoli R, Votto M, Licari A, et al. Severe acute respiratory syndrome coronavirus 2 (SARS -CoV-2) infection in children and adolescents: A systematic review. JAMA Pediatr. 2020;174 (9):882-889.

5. Paquette D, Bell C, Roy M, et al. Laboratoryconfirmed COVID-19 in children and youth in Canada, January 15-April 27, 2020. Can Commun Dis Rep. 2020;46(5):121-124.

6. Chao JY, Derespina KR, Herold BC, et al. Clinical characteristics and outcomes of hospitalized and critically ill children and adolescents with coronavirus disease 2019 at a tertiary care medical center in New York City. J Pediatr. 2020;223:14-19. doi:10.1016/j.jpeds.2020.05.006

7. Shekerdemian LS, Mahmood NR, Wolfe KK, et al. Characteristics and outcomes of children with coronavirus disease 2019 (COVID-19) infection admitted to US and Canadian pediatric intensive care units. JAMA Pediatr. 2020;174(9):868-873. doi:10.1001/jamapediatrics.2020.1948

8. $\mathrm{Wu} \mathrm{Z,} \mathrm{McGoogan} \mathrm{JM.} \mathrm{Characteristics} \mathrm{of} \mathrm{and}$ important lessons from the coronavirus disease 2019 (COVID-19) outbreak in China: Summary of a report of 72314 cases from the Chinese center for disease control and prevention. JAMA. 2020;323(13):1239-1242.

9. Kocabaş E, Ersöz D, Karakoç F, et al. Turkish thoracic society consensus report on diagnosis and treatment of community acquired pneumonia in children. Turk Thoracic J. 2009;10:1-24.

10.COVID-19 (SARS-CoV-2 Enfeksiyonu) genel bilgiler epidemiyoloji ve tanı. Bilimsel Danışma Kurulu çalışması. TC Sağlık Bakanlığı 29 Haziran 2020. https://covid19.saglik.gov.tr/TR66337/genel-bilgiler-epidemiyoloji-ve-tani. Erişim tarihi 30 Haziran 2020.

11. Asrak HK, Belet N, Güzin AÇ, et al. COVID19'lu çocuklarda akciğer grafisi, bilgisayarlı

\section{REFERENCES}


tomografi endikasyonları ve potansiyel riskleri. http://www.cocukenfeksiyondernegi.org. Erişim tarihi 25 Mayıs 2020.

12. Bialek S, Gierke R, Hughes M, McNamara LA, Pilishvili T, Skoff T. Coronavirus disease 2019 in children - United States, February 12-April 2, 2020. Morb Mortal Wkly Rep. 2020;69 (14):422-426. doi:10.15585/MMWR.MM6914E4

13. Wang W, Xu Y, Gao R, et al. Detection of SARS -CoV-2 in different types of clinical specimens. JAMA. 2020;323(18):1843-1844. doi:10.1001/jama.2020.3786

14. Sethuraman N, Jeremiah SS, Ryo A. Interpreting diagnostic tests for SARS-CoV2. JAMA. 2020;323(22):2249-2251. doi:10.1001/ jama.2020.8259

15. Chang TH, Wu JL, Chang LY. Clinical characteristics and diagnostic challenges of pediatric COVID-19: A systematic review and metaanalysis. J Formos Med Assoc. 2020;119(5):982989. doi:10.1016/j.jfma.2020.04.007

16. Hasan A, Mehmood N, Fergie J. Coronavirus Disease (COVID-19) and pediatric patients: A review of epidemiology, symptomatology, laboratory and imaging results to guide the development of a management algorithm. Cureus. 2020;12(3):e7485. doi:10.7759/cureus. 7485

17. Xia W, Shao J, Guo Y, Peng X, Li Z, Hu D. Clinical and $\mathrm{CT}$ features in pediatric patients with COVID-19 infection: Different points from adults. PediatrPulmonol. 2020;55(5):1169-1174. doi:10.1002/ppul.24718

18. Meng H, Xiong R, He R, et al. CT imaging and clinical course of asymptomatic cases with COVID-19 pneumonia at admission in Wuhan, China. J Infect. 2020;81(1):e33-e39. doi:10.1016/ j.jinf.2020.04.004

19.Zachariah P, Johnson CL, Halabi KC, et al. Epidemiology, clinical features, and disease severity in patients with Coronavirus Disease 2019 (COVID-19) in a children's hospital in New York City, New York. JAMA Pediatr. 2020;174(10):e202430. doi:10.1001/ jamapediatrics.2020.2430

20. Shen KL, Yang YH, Jiang RM, et al. Updated diagnosis, treatment and prevention of COVID19 in children: experts' consensus statement (condensed version of the second edition). World J Pediatr. 2020;16(3):232-239. doi:10.1007/ s12519-020-00362-4
21. Qiu H, Wu J, Hong L, Luo Y, Song Q, Chen D. Clinical and epidemiological features of 36 children with coronavirus disease 2019 (COVID-19) in Zhejiang, China: an observational cohort study. Lancet Infect Dis. 2020;20(6):689-696. doi:10.1016/S1473-3099(20)30198-5 
Table 1. Demographics and characteristics of 54 children hospitalized for COVID-19.

\begin{tabular}{|c|c|c|c|c|}
\hline & \multirow[b]{2}{*}{ All cases } & \multicolumn{2}{|c|}{ RT-PCR } & \multirow[b]{2}{*}{ p } \\
\hline & & Positive & Negative & \\
\hline & $\mathrm{N}=54$ & $\mathrm{~N}=24$ & $\mathrm{~N}=30$ & \\
\hline \multicolumn{5}{|l|}{ Age } \\
\hline Median (Minimum-Maximum)-month & $121.5(1-214)$ & $153(1-214)$ & $83.5(2-203)$ & $0.207^{1}$ \\
\hline \multicolumn{5}{|l|}{ Gender n (\%) } \\
\hline Female & $26(48.1)$ & $12(50)$ & $14(46.7)$ & $0.808^{2}$ \\
\hline Male & $28(51.9)$ & $12(50)$ & $16(53.3)$ & \\
\hline \multicolumn{5}{|l|}{ No of family members infected $n(\%)$} \\
\hline 0 contact $^{\mathbf{a}}$ & $18(33.3)$ & $3(12.5)$ & $15(50)$ & $0.014^{2}$ \\
\hline 1 contact & $25(46.3)$ & $15(62.5)$ & $10(33.3)$ & \\
\hline$\geq 2$ contact & $11(20.4)$ & $6(25)$ & $5(16.7)$ & \\
\hline \multicolumn{5}{|l|}{ Clinical Symptoms n (\%) } \\
\hline Cough & $24(44.4)$ & $15(62.5)$ & $9(30)$ & \\
\hline Fever & $19(135.2)$ & $6(25)$ & $13(43.3)$ & \\
\hline Smell/Taste loss & $1(1.9)$ & $1(4.2)$ & $0(0)$ & \\
\hline Shortness of breath & $7(13)$ & $0(0)$ & $7(23.3)$ & \\
\hline Vomiting, diarrhea & $3(5.6)$ & $2(8.3)$ & $1(3.3)$ & \\
\hline \multicolumn{5}{|l|}{ Severityn (\%) } \\
\hline Mild & $28(51.9)$ & $13(54.2)$ & $15(50)$ & \\
\hline Moderate & $21(38.9)$ & $11(45.8)$ & $10(33.3)$ & \\
\hline Severe & $4(7.4)$ & $0(0)$ & $4(13.3)$ & \\
\hline Critical & $1(1.9)$ & $0(0)$ & $1(3.3)$ & \\
\hline \multicolumn{5}{|l|}{ Hospitalization Date } \\
\hline Median (Minimum-Maximum)-day & $5(1-13)$ & $5(2-13)$ & $5(1-12)$ & $0.453^{1}$ \\
\hline \multicolumn{5}{|l|}{ Treatment n (\%) } \\
\hline None & $8(14.8)$ & $6(25)$ & $2(6.7)$ & \\
\hline Oseltamavir & $12(22.2)$ & $1(4.2)$ & $11(36.7)$ & \\
\hline Azithromycin & $13(24.1)$ & $7(29.2)$ & $6(20)$ & \\
\hline Chloroquine & $2(3.7)$ & $1(4.2)$ & $1(3.3)$ & \\
\hline Azithromycin + Chloroquine & $14(25.9)$ & $8(33.3)$ & $6(20)$ & \\
\hline Other & $5(9.3)$ & $1(4.2)$ & $4(13.3)$ & \\
\hline \multicolumn{5}{|l|}{ Comorbidities (n=6) n (\%) } \\
\hline Secondary infection & $3(50)$ & $0(0)$ & $3(60)$ & \\
\hline Asthma, Epilepsy, IBD, DM & $3(50)$ & $1(100)$ & $2(40)$ & \\
\hline
\end{tabular}

${ }^{a}$ significantly different groups; ${ }^{1}$ Mann-Whitney U test; ${ }^{2}$ Chi-square Test; COVID-19: coronavirus disease 2019; IBD: inflammatory bowel disease; DM: diabetes mellitus. 
Table 2. Laboratory findings of 54 children hospitalized for COVID-19.

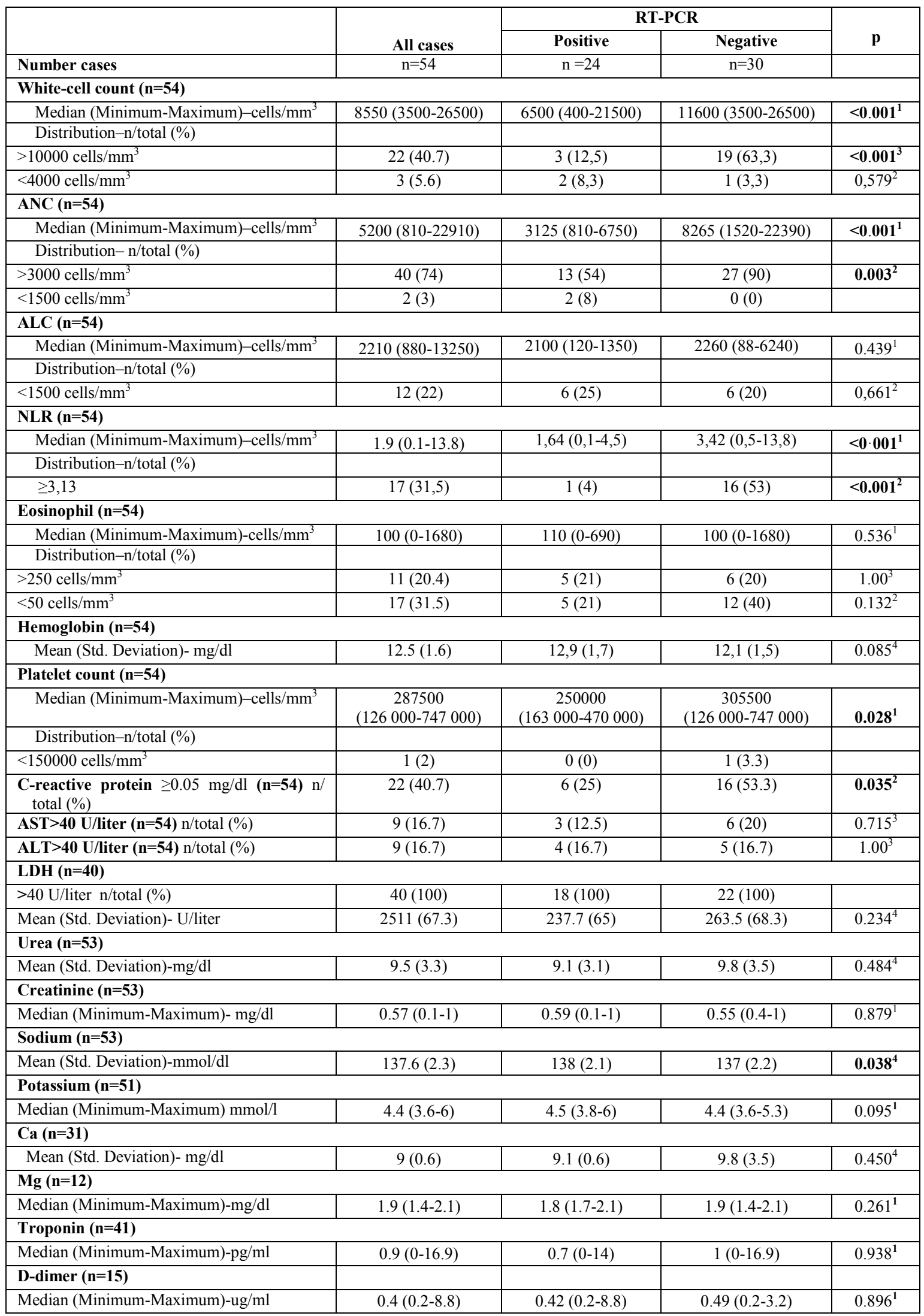

${ }^{1}$ Mann-Whitney; ${ }^{2}$ Pearson Chi-Square Test; ${ }^{3}$ Fisher's Exact Test; ${ }^{4}$ Independent Samples T test; AST: Aspartate aminotransferase; ALT: Alanine aminotransferase; LDH: Lactate dehydrogenase; ANC: Absolute neutrophil count; ALC:Absolute lymphocyte count; NLR: neutrophil lymphocyte ratio. 
Table 3. Radiological findings of 54 children hospitalized for COVID-19.

\begin{tabular}{|c|c|c|c|c|}
\hline & & RT & $\overline{C R}$ & \\
\hline & All cases & Positive & Negative & $\mathbf{p}$ \\
\hline Number of all Cases & $\mathrm{n}=54$ & $\mathrm{n}=24$ & $\mathrm{n}=30$ & \\
\hline Chest X-Ray $(n=43)$ & & & & \\
\hline Normal & $16(37.2)$ & $4(26.7)$ & $12(42.9)$ & $0.295^{1}$ \\
\hline Abnormal & $27(62.8)$ & $11(73.3)$ & $16(57.1))$ & \\
\hline CT $(n=26)$ & & & & \\
\hline Normal & $3(11.5)$ & $1(9.1)$ & $2(13.3)$ & \\
\hline Classic/Probable COVID-19 & $19(73.1)$ & $10(90.9)$ & $9(60)$ & \\
\hline Non COVID-19 & $4(15.4)$ & $0(0)$ & $4(26.7)$ & \\
\hline CT Severity $(n=19)$ & & & & \\
\hline Mild & $10(52.6)$ & $5(50)$ & $5(55.6)$ & \\
\hline Moderate & $6(31.6)$ & $4(40)$ & $2(22.2)$ & \\
\hline Severe & $3(15.8)$ & $1(20)$ & $2(22.2)$ & \\
\hline Unilateral/Bilateral $(n=20)$ & & & & \\
\hline Unilateral & $10(50)$ & $5(50)$ & $5(50)$ & $1.00^{1}$ \\
\hline Bilateral & $10(50)$ & $5(50)$ & $5(50)$ & \\
\hline
\end{tabular}

${ }^{1}$ : Chi-square test. 
Table 4. Vital signs, oxygen saturations and blood gases of patients.

\begin{tabular}{|c|c|c|c|c|}
\hline & \multirow[b]{2}{*}{ All cases } & \multicolumn{2}{|c|}{ RT-PCR } & \multirow[b]{2}{*}{$\mathbf{p}$} \\
\hline & & Positive & Negative & \\
\hline \multicolumn{5}{|l|}{ Fever (24/30) } \\
\hline Median (Minimum-Maximum) & $36.8(36-38.9)$ & $36.8(36-38)$ & $36.9(36.5-38.9)$ & $0.27^{1}$ \\
\hline \multicolumn{5}{|l|}{ Heart Rate (24/30) } \\
\hline Median (Minimum-Maximum) & $118.5(74.180)$ & $100.5(74-159)$ & $121(78-180)$ & $0.05^{1}$ \\
\hline \multicolumn{5}{|l|}{ Respiratory Rate (24/30) } \\
\hline Median (Minimum-Maximum) & $28(18-56)$ & $24(18-48)$ & $29(18-56)$ & $0.17^{1}$ \\
\hline \multicolumn{5}{|l|}{$\mathrm{SpO}_{2}$ on room air $(24 / 30)$} \\
\hline Median (Minimum-Maximum) & $98(88-100)$ & $98(92-100)$ & $95.5(88-99)$ & $<0.001^{1}$ \\
\hline \multicolumn{5}{|l|}{ Oxygen Therapy $(24 / 30)$} \\
\hline Non $(\%)$ & $35(64.8)$ & $22(91.7)$ & $13(43.3)$ & \\
\hline Venturi Mask n (\%) & $13(24.1)$ & $1(4.2)$ & $12(40)$ & \\
\hline Nasal cannulan $(\%)$ & $5(9.3)$ & $1(4.2)$ & $4(13.3)$ & \\
\hline Invasive mechanical ventilation $\mathrm{n}(\%)$ & $1(1.8)$ & $0(0)$ & $1(3.3)$ & \\
\hline \multicolumn{5}{|l|}{ Oxygen Therapy (24/30) } \\
\hline Non $(\%)$ & $35(64.8)$ & $22(91.7)$ & $13(43.3)$ & \multirow[t]{2}{*}{$<0.001^{2}$} \\
\hline Yes n $(\%)$ & $19(35.2)$ & $2(8.3)$ & $17(56.7)$ & \\
\hline \multicolumn{5}{|l|}{ Duration of Oxygen Therapy (24/30) } \\
\hline Median (Minimum-Maximum) & $0(0-5)$ & $0(0-2)$ & $1(0-5)$ & $0.001^{1}$ \\
\hline$<1$ day* $^{*}(\%)$ & $35(64.8)$ & $22(91.7)$ & $13(43.3)$ & \multirow{3}{*}{$0.001^{3}$} \\
\hline 1 day $\mathrm{n}(\%)$ & $11(20.4)$ & $1(4.2)$ & $10(33.3)$ & \\
\hline$\geq 2$ day $n(\%)$ & $8(14.8)$ & $1(4.2)$ & $7(23.3)$ & \\
\hline \multicolumn{5}{|l|}{24 hour HR (24/30) } \\
\hline Median (Minimum-Maximum) & $91.5(70-170)$ & $88(70-146)$ & $98(74-170)$ & $0.26^{1}$ \\
\hline \multicolumn{5}{|l|}{24 hour RR (24/30) } \\
\hline Median (Minimum-Maximum) & $22(18-72)$ & $22(18-40)$ & $22(18-72)$ & $0.13^{1}$ \\
\hline \multicolumn{5}{|l|}{ 24.hour $\mathrm{SpO}_{2}$ on roomair $(24 / 30)$} \\
\hline Median (Minimum-Maximum) & $99(92-100)$ & $99(96-100)$ & $98.5(92-100)$ & $0.055^{1}$ \\
\hline \multicolumn{5}{|l|}{ 24.Spo 2 Oxygen (1/7) } \\
\hline Median (Minimum-Maximum) & $98(98-100)$ & 98 & $98(98-100)$ & \\
\hline \multicolumn{5}{|l|}{ pH $(6 / 20)$} \\
\hline Median (Minimum-Maximum) & $7.33(7.21-7.47)$ & $7.32(7.30-7.41)$ & $7.34(7.21-7.47)$ & $0.60^{1}$ \\
\hline \multicolumn{5}{|l|}{ pCO2 (6/20) } \\
\hline Median (Minimum-Maximum) & $38(30.6-56)$ & $39(30.6-56)$ & $38(32-55)$ & $0,58^{1}$ \\
\hline \multicolumn{5}{|l|}{$\mathrm{HCO3}(6 / 20)$} \\
\hline Median (Minimum-Maximum) & $23.6(18.6-28)$ & $23.3(20.6-26.2)$ & $23,7(18,6-28)$ & $0,64^{1}$ \\
\hline \multicolumn{5}{|l|}{ Lactate $(6 / 20)$} \\
\hline Median (Minimum-Maximum) & $1.1(0.6-2.8)$ & $1.05(0.8-1.3)$ & $1,3(0,6-2,8)$ & $0,14^{1}$ \\
\hline \multicolumn{5}{|l|}{$\mathrm{BE}(\mathbf{6} / \mathbf{2 0})$} \\
\hline Median (Minimum-Maximum) & $1.25(0.3-6.4)$ & $1.25(0.3-2.2)$ & $1,4(0,4-6,4)$ & $0,34^{1}$ \\
\hline
\end{tabular}

${ }^{\mathrm{a}}$ :Significantly different groups; ${ }^{1}$ Mann Whitney U test; ${ }^{2} \mathrm{Chi}$-square Test ${ }^{3}$; Fisher Exact Test. 


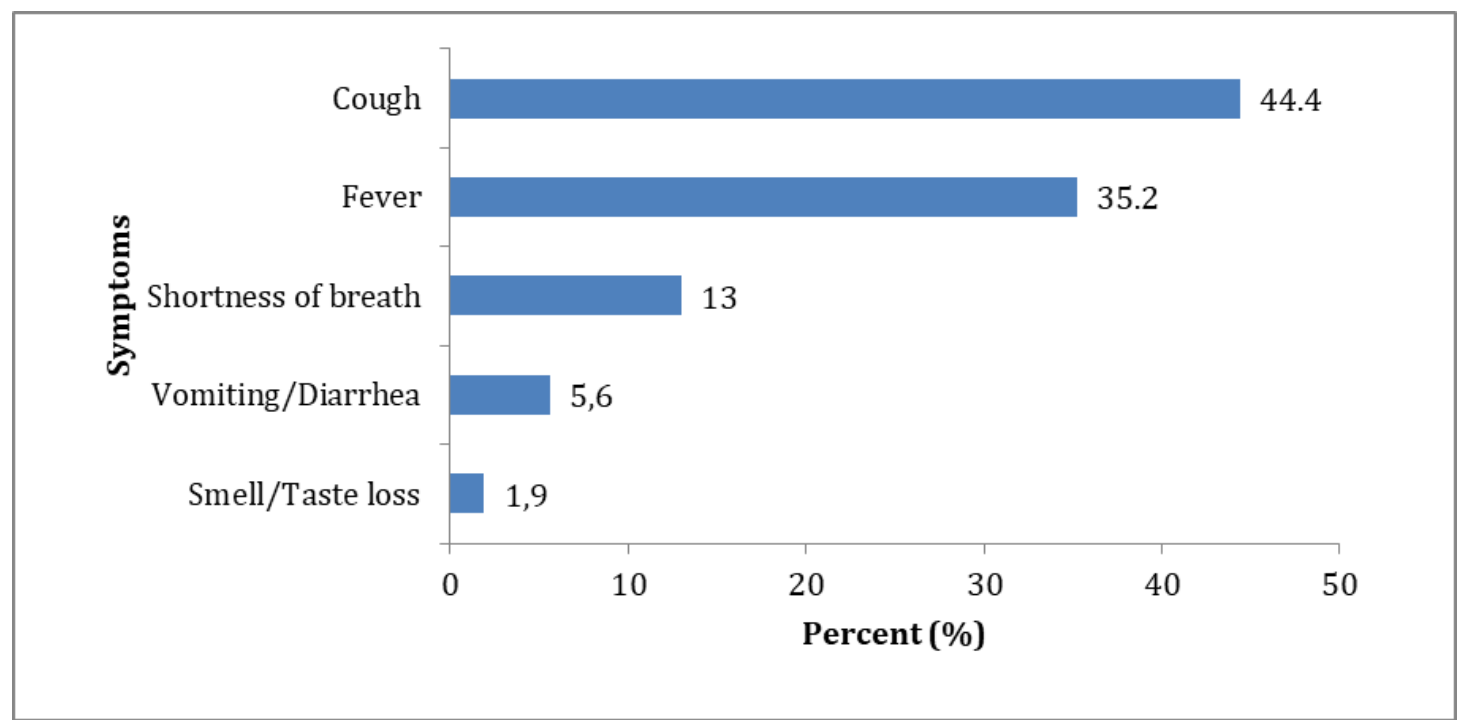

Figure 1. The most common clinical symptoms of 54 children. 